\title{
THE BIOGRAPHICAL FASHIONING OF THE AMERICAS' FIRST SAINT: SANTA ROSA DE LIMA (1586-1617)
}

\author{
STEPHEN M. HART
}

The first published account of the life and death of the first saint of the Americas, Santa Rosa de Lima (1686-1617), a biography written by one Leonardus Hansen, Vita mirabiliis et mors pretiosa venerabiliis sororis Rosae de S. Maria Limensis Ex Tertio Ordine S.P. Dominici ad Sanctissimum D.N. Alexandrum VII Pontificem Max., Excerpta \& collecta per P.M.F. Leonardum Hansen Provincialem Angliae, \& Socium Reverendissimi P. Magist. Generalis Ord. Prae. (Rome: Angeli Tinassi, 1664), to give its full title, has cast a long shadow in the tradition of life-writing of Peru's first saint and, as a result, Hansen's version of Santa Rosa has remained remarkably resistant to change over the last 350 years. ${ }^{1}$ This is no doubt because it was an enormously successful book in the late seventeenth century, leading to two Latin re-issues, in 1668 - this time published in Louvain, Belgium - and a third in 1680, back in Rome, ${ }^{2}$ two abridged Latin versions published in 1665 and 1668 based on Hansen's original text, ${ }^{3}$ four Spanish translations published in $1665,{ }^{4} 1668,{ }^{5} 1670,{ }^{6}$ and $1671,{ }^{7}$ an Italian translation in

\footnotetext{
1 I express my gratitude to the British Academy for the following two research grants ('Santa Rosa de Lima: The Evolution of a Saint' 2013-2015: project No: SG121483; 26 June 2013-30 June 2015; and 'A Critical Edition of ASV2208, "Rosa a Sancta Maria III Ord. S. Dominici: Supplementa Proc.", 1670, 67 fols.; 1 October 2017-30 September 2019), and to the Leverhulme Trust for a Senior Research Fellowship ('A Critical Edition of the Apostolic Process of Santa Rosa de Lima (1586-1617)'; 1 October 2015-30 September 2017), which allowed me to to conduct research at various archives in the UK, Peru, Spain and Italy.

2 Domingo Ángulo, Santa Rosa de Santa María: estudio bibliográfico (Lima: Sanmartí y Cía, 1917), p. 89, and pp. 104-05.

${ }^{3}$ F. Antonio González de Acuña, Sponsa Christi Rosa de S. Maria, Virgo Peruana, Tertii Ordinis S.P. Dominici, Compendio Enarrata (Rome: Nicolai Angeli Tinassi, 1665), Ref. X2797, Archivum Generale Ordinis Praedicatorum (A.G.O.P), Basilica of Saint Sabina, Rome; and by the same author, Rosa de S. Maria Virgo Limensis e Tertio Ordine SS. P. Dominici Mirae Integritatis Rarae Innocentiae Summae Perfectionis Studiossima Seraphicae Virginis S. Catherinae Senensis eiusdem Ordinis Imitratrix (Rome: Augustae Vindelicorum, 1668).

${ }^{4}$ Vida admirable, y muerte preciosa de la Venerable Madre Soror Rosa Maria, Peruana, en Lima, de la Tercera Orden de Predicadores, translated by Beysselius de Coronis in Proemio (Valencia: Impressor del Santo Tribunal, y de la Ciudad, junto al Molino de Rovella, 1665); see reference in Domingo Ángulo, pp. 81-82.

${ }^{5}$ La Bienaventurada Rosa Peruana de S. Maria de la Tercera Orden de Santo Domingo, Su admirable vida y preciosa muerte Restituida Del Latino Idioma, en que la historió el M.R.Padre Maestro Fr. Leonardo Hansen...., translated by Padre Maestro Fr. lacinto de Parra (Madrid: Melchor Sanchez, Impressor de Libros, 1668); see reference in Domingo Ángulo, pp. 89-90. There were two other translations published that year; Breve y sumaria relacion de la vida, muerte, y solemne beatificacion de la bienaventurada Rosa de Santa Maria (Barcelona: Antonio Lacavalleria, 1668), and Breve relacion de la vida de la beata Rosa de Sta. Maria, del Orden de Nuestro Padre Santo Domingo (Rome: Orden de Santo Domingo, 1668).

${ }^{6}$ Historia de la Ba. Me. Rossa de Santa Maria dela Orden de Predicadores... (Madrid: Impressora del Reyno, 1670).

${ }^{7}$ According to Domingo Ángulo the Spanish version published in 1671, and authored by P. Fr. Antonio de Lorea, was not a translation of Hansen's original but a new original work by Lorea; see Ángulo, pp. 71-72.
} 
$1666,{ }^{8}$ a German translation in $1667,{ }^{9}$ two independent French translations published in $1668,{ }^{10}$ a Dutch translation in $1668,{ }^{11}$ a second abridged French translation in $1669,{ }^{12}$ two Portuguese translations in 1669, one of which was republished in 1674, ${ }^{13}$ and an English translation in 1847. ${ }^{14}$

Though a number of other biographies followed, Hansen's Vita mirabilis et mors pretiosa of 1664 is the account of her life which has been basically unchallenged for more than three centuries. ${ }^{15}$ This is clear if we look at the two major biographies written on Santa Rosa in the nineteenth century, José Manuel Bermúdez's Vida de la gloriosa virgen dominicana Santa Rosa de Santa María (1827); and José Antonio Catá de Calella's Vida portentosa de la esclarecida Virgen Santa Rosa de Santa María (1886). ${ }^{16}$ Though these two works (annoyingly!) very rarely cite their sources, neither departs in any substantial way from the seventeenth-century biographical version of Rosa epitomized by Leonardus Hansen's work. Even when Bermúdez refers to the documents of the Apostolic Process, citing them in an occasional footnote (see, for example, Bermúdez, p. 93, p. 121, p. 155 and p. 207), and he refers to his access to the Ordinary as well as the Apostolic Process in his prologue (pp. 3-4), his narrative for all this does not diverge in any substantial way from Hansen's 1664 narrative. This is not surprising given his self-confessed admiration for Hansen's work: "pero me retraían de tan útil empresa mi corto talento y el respeto a los que, antes que yo, pusieron las manos en ella, en especial el cultísimo Dominicano Leonardo Hansen, superior a todo elogio' Bermúdez (p. 3). And while Catá de Calella's biography offers what may be described as a more nuanced biography of Santa Rosa in that it discusses the veracity and reliability of its sources on a few occasions, thereby differentiating between them. It also discusses the Sumario on p. 14, the Apostolic Process on p. 90, and compares testimonies of Rosa, particularly Juan del Castillo versus Juan de Lorenzana on pp. 129-31, nevertheless, for all this, it does not depart substantially from the version of Rosa's life offered by

${ }^{8}$ La Rosa Peruana o vero Vita della Sposa di Christo Suor Rosa de Santa Maria Nativa della Citta di Lima Nel Regno del Perù, del Terz'Ordine di San Domenico. Descritta Da F. Serafino Bertolini Dominicano Maestro in Sacra Teologia, e Penitenziero Apostolico nella Basilica di S. Maria Maggiore (Rome: Tinassi, 1666), 615 pp. Angulo also refers to a translation which appeared the previous year, Vita della Sposa di Giesú (sic)-Christo Rosa di Santa Maria (1665), translated by D. Fr. Domingo María Marchesse, which was so successful that it led to a second edition in 1668; see Domingo Ángulo, pp. 70-71.

${ }^{9}$ Das Wunderlbarliche Lebe und vil werther todt der ehrwürdigen schwester Rosa de S. Maria von Lima gebürtig aus der dritten Regel des H. Vatters Dominici (Ynsprugg: Michael Wagner, 1667).

${ }^{10}$ These were La vie de la bienhereuse épouse de Jésus-Christ Soeur Rose de Sainte Marie, Religieuse du Tiers Ordre de S. Dominique, originaire du Pérou dans les Indes Occidentales, traduite du latin, imprimé á Rome, translated by R.P. Jean Baptiste Feuillet (Paris: André Cramoisy, 1668); and La vie de S. Rose de Sainte Marie, Religieuse du Tiers Ordre de S. Dominique, originaire de la Ville de Lima, translated by André Faure (Bordeaux: Jacques Mongiron Illanges, 1668). The first translation was based on González de Acuña's abridged version (see footnote 3) and the second on Hansen's text.

${ }^{11}$ Het Wonder Leven de Kostelyche Doodt, met het Begrijp der Mirakelen, \&c, van de H. Rosa de S. Maria van Lima in Peru, Van den Derdenm Reghel van den H. Dominicus (Brussels: Philips Vleugaert, 1668).

12 The Feuillet translation was republished a year later in 1669; see Ángulo, pp. 96-97.

${ }^{13}$ The 1674 Portuguese edition is entitled Vida admiravel e morte preziosa da Bemaventurada Santa Roza de Santa Maria, Natural da cidade de Lima, Religiosa da Terceira Ordem de N.P.S. Domingos, recopilada em lengua Latina pello M.R.P. Mestre Frei Leonardo Hansen, Provincial de Inglaterra, \& Companheiro do R. Mestre Geral da Ordem dos Pregadores, translated by Fr. Domingos Freire (Lisbon: Joam da Costa, 1674); Ángulo lists a 1668 early edition of this texto as well as another translation, Epitome da vida e morte da Gloriosa e Admiravel Virgem Rosa de Sancta Maria, Religiosa Terceira da Ordem des Pregadores dividido en dous sermoes, translated by Alvaro Leitao (Lisbon, 1669). The translation by Leitao is presumably of González de Acuña's abridged text (see footnote 3).

${ }^{14}$ F.W. Faber, The Lives of S. Rose of Lima, The Blessed Colomba of Rieti, and of S Juliana Falconieri (London: Thomas Richardson and Son, 1873). Santa Rosa's biography in English is at pp. 1-181.

${ }^{15}$ Ángulo criticises Bermúdez's biography, accusing him of relying too heavily on Lorea's work; see Ángulo, pp. 72-73. He singles out for praise the nineteenth-century French biography, Thomas de Busierre, Le Pérou de Sainte Rose de Lima (1863) which emphasises the social context in which Rosa grew up, and notes that he attacked Adrian Baillet's Vies des Saints (1701) in which the latter author had dismissed the account of Rosa's austerities as an example of legendary embellishment; see Ángulo, pp. 74-75.

${ }^{16}$ José Manuel Bermúdez, Vida de la gloriosa virgen dominicana Santa Rosa de Santa María, natural de Lima: patrona principal de las Américas (Lima: Imprenta de los Huérfanos, 1827); and José Antonio Catá de Calella's Vida portentosa de la esclarecida Virgen Santa Rosa de Santa María, vulgo Santa Rosa de Lima (Barcelona: Librería y tipografía católica, 1886). 
Hansen; both nineteenth-century accounts offer what might be called a freeze-dried, seventeenthcentury version of Rosa's life. More recent biographies such as by P. Luis Alfonso Getino, ${ }^{17}$ Rubén Vargas Ugarte, ${ }^{18}$ Luis Millones, ${ }^{19}$ Gabriella Anodal, ${ }^{20}$ José Antonio del Busto Duthurburu, ${ }^{21}$ and Sor María del Mar Castro Malo, O.P., ${ }^{22}$ do not essentially change the record - the narrative of Rosa's life is principally derived from Hansen's biography. But recently some new evidence has emerged which casts doubt on the historical fidelity of Leonardus Hansen's text, particularly with regard to the authorship of the text as well as the account it offers of Santa Rosa de Lima's miracles. The latter, of course, has important implications (to be discussed below) for the miracles for which Santa Rosa's intervention is claimed and which are the bedrock on which her sanctity rests.

Before we can address these questions in Leonardus Hansen's text, we need to look in more detail at the pre-history of the Vita mirabiliis et mors pretiosa venerabiliis sororis Rosae de S. Maria, that is, how it came into being, which texts and manuscripts it relied on and how it fitted into the cultural practice of sacred life-writing as it functioned at that time in the Hispanic world of the late seventeenth century. I will sketch out this pre-history in three discrete parts, as based on (i) the Ordinary Process, (ii) the Apostolic Process, and (iii) the deliberations of the Sacred Congregation of Rites. I will also restrict the analysis to textual test-cases rather than images, since the latter constitute a case apart. Santa Rosa's iconography has, indeed, been amply studied. Ramón Mujilla Pinilla's magisterial study of mysticism, politics and iconography of the 'Patron of the Americas', for example, analyses the various phases as the Virgin Astraea, the Virgin of the Sun, the Indian Immaculate Virgin, the Rose of Lima, Saint Rose of the Andes, and La Rosa Criolla. ${ }^{23}$ Whereas Mujica Pinilla's study gives a clear sense of how Rosa's iconography has changed over time - indeed, how she changed from a religious figure in the seventeenth century to a political and independentista figure by the nineteenth century - we do not have an equivalent version of her textual transformation during the same period, or what I shall be calling in this essay, her biographical fashioning. While there has been some important work carried out on the process of canonisation, ${ }^{24}$ there has not been until relatively recently - as mentioned above - any systematic study of the historical record. ${ }^{25}$

The investigation into Rosa's blessedness began just 8 days after death, on 1 September 1617, at the instigation of the Procurator of the Dominican Order, Fray Francisco de Valcázar. The interrogation of witnesses began on 5 September based on a questionnaire consisting of 32 questions, 75 witnesses were called, and the interrogation was concluded eight months later on 7 April $1618 .{ }^{26}$ Another copy of the Beatification documents was then drawn up - entitled 'Traslado Autentico delas Informaciones

\footnotetext{
${ }^{17}$ P. Alfonso Getino, La patrona de América ante los nuevos documentos (Madrid: Revista de las Españas, 1937).

${ }^{18}$ Rubén Vargas Ugarte, $3^{\text {rd }}$ edition, Vida de Santa Rosa de Lima (Buenos Aires: Imprenta López, 1959).

${ }^{19}$ Luis Millones (ed.), Una partecita del cielo: la vida de Santa Rosa de Lima narrada por Gonzalo de la Maza a quien ella llamaba padre (Lima: Horizonte, 1993).

${ }^{20}$ Gabriella Anodal, $3^{\text {rd }}$ edition, Santa Rosa da Lima: una donna alla conquista dell'America (Bologna: Edizioni Studio Domenicano, 2007).

21 José Antonio del Busto Duthurburu, Santa Rosa de Lima (Lima: PUCP-Fondo Editorial, 2006), $2^{\text {nd }}$ edition 2016.

22 Sor María del Mar Castro Malo, O.P., Ofrenda a Santa Rosa de Lima (Alcalá de Henares: COPYHENARES S.L., 2012).

${ }^{23}$ Ramón Mujica Pinilla, Rosa limensis: Mística, política e iconografía en torno a la patrona de América (Fondo de Cultura Económica, 2001), pp. 249-360.

${ }^{24}$ See, for example, Teodoro Hampe Martínez, Santidad e identidad criolla: estudio del proceso de canonización de Santa Rosa (Cuzco: Centro de Estudios Regionales Andinos 'Bartolomé de las Casas', 1998).

${ }^{25}$ The Ordinary Process was published in 2002, and the Apostolic Process in 2017; see Hernán Jiménez Salas, O.P. (ed.), Primer Proceso Ordinario para la canonización de Santa Rosa de Lima (Lima: Monasterio de Santa Rosa de Santa María de Lima, 2002), 604 pp.; and Stephen M. Hart (ed.), Edición crítica del Proceso Apostólico de Santa Rosa de Lima (1630-1632): Congr. Riti Processus 1573, Archivum Secretum Vaticanum (Lima: Editorial Cátedra Vallejo, 2017), $782 \mathrm{pp}$.

${ }^{26}$ The original manuscript containing the 75 testimonies - in Spanish - has been conserved to this day in the Monasterio de Santa Rosa de Santa María in Lima, as confirmed to me in an interview with Sor María Torres de Jesús, O.P., the Mother Superior of the Monastery, in Lima, on 2 July 2013. A transcription of this master copy has now been published in the above-mentioned edition by Hernán Jiménez Sala, Primer proceso ordinario para la canonización de Santa Rosa de Lima (2002).
} 
de la Vida Sanctidad Muerte y Milagros de la Bendita Rosa de Santa María...', measuring 338 folios. ${ }^{27}$ The whole document was signed and authenticated by the Archbishop Baltasar de Padilla and put on a ship to Spain, leaving in the late spring or early summer of 1618. The entire process had taken 333 days and, once received in Spain, this document was prepared for submission to the Holy See. Master Prior of the Province Agustín de Vega and General Predicator and Apostolic Notary Francisco de Figueroa were charged with producing a Latin version of the text. They completed the task on 16 April 1619, producing a new 463-folio text entirely in Latin entitled 'Informatio Ju[ri]dica Ante Archepiscopum Civitatis Regum...'. ${ }^{28}$ Despite some subsequent hiccoughs - not all of the testimonies were translated into Latin (three were, rather mysteriously, left out), and Rosa's veneration was vetoed in Lima for part of $1624^{29}$ - when the case for Rosa's canonization was eventually brought before and examined by the Sacred Congregation of Rites in Rome on 22 March 1625, it was evaluated as 'most sacred' ('sanctissimo videretur'), and recommended for submission to the Apostolic Tribunal. ${ }^{30}$ As a result the case was authorised to be converted to an Apostolic investigation, ${ }^{31}$ the relevant remissorial and compulsorial bulls, signed in Rome on 10 May 1625, were sent to Lima, authorising a second investigation focussing specifically on Rosa's saintliness, virtues and miracles. 32

The canonization process formally commenced on 10 April 1630. The interviews took place in two phases, the first of which took place from 17 May 1630 until 4 December 1631, and the second of which took place from 13 December 1631 until 3 June 1632; the process captured the testimony of 188 depositions in all. ${ }^{33}$ There were two main differences between the Beatification Process and the Apostolic Process. The canonization file is much more substantial (188 depositions as compared to just 75 in the Beatification Process), and the moratorium that occurred in December 1631 allowed for new compulsorial documents to be taken into account, consisting a letter written by Nicolás de Agüero, dating back to 1617, a highly valuable 29-chapter biography (the first ever written), and four Latin poems written in eulogy of Rosa's virtues. The complete document was bundled up and sent to the Holy See in a Spanish vessel that left Callao on 15 June 1632, with Dr Sebastián de Sandoval acting

27 'Traslado Autentico delas Informaciones de la Vida Sanctidad Muerte y Milagros de la Bendita Rosa de Santa María, Natural de la Ciudad de los Reyes del Peru, del Abito de la Orden de Sancto Domingo, del Pedimento del Procurador, por Mando del Illustrissimo Don Bartolome Lobo Guerrero Arçobispo dela dicha Ciudad, del Concejo de su Magestad Juez de la Causa, Sacado por Jayme Blanco Notario Publico de su Camara y Gobierno Escrito en Trescientas y Treinta y Tres Dias, Jayme Blanco, Notario Publico', 338 fols., Archivum Secretum Vaticanum, Arch. Congr. SS, Rituum Processus, 1570, hereafter ASV1570; the 'Proceso Ordinario' is in three volumes (including translations), ASV, Arch. Congr. SS, Rituum Processus, that is, mansucripts 1570, 1571, and 1572. Teodoro Hampe Martínez lists ASV1570 as having 334 fols. (Santidad e identidad criolla, p. 19, n19), but, if the last document in the manuscript is also counted, it comes to 338 fols.

28 'Informatio Ju[ri]dica Ante Archepiscopum Civitatis Regum in Indiis Occidentalibus de Vita et Miraculis Venerabilis Sororis, Rosa De S. Maria Ordinis Predicatoris. Procuratore P. e Miró, fr. Luca De Leon Garavito, eius de Ordinis, ex Provincia Peruanis', 463 fols., Archivum Secretum Vaticanum, Arch. Congr. SS. Rituum Processus, 1572.

${ }^{29}$ Stephen M. Hart, Santa Rosa de Lima: la evolucion de una santa (Lima: Cátedra Vallejo, 2017), pp. 60-66.

30 Joannes Migetius, 'Limana seu Civitatis Regum Beatificationis et Canonizationis Servae Dei Rosae a Sancta maria Ordinis Sanctis Dominici. Discursus Super Processu Remissoriali in Specie, ac Statu Causa, et Vera Gendis pro illius, Reassumptione et Ulteriori Progressu', 62 fols.; fol. 1r; Archivum Secretum Vaticanum, Arch. Congr. SS. Rituum Processus, 1580; hereafter ASV1580.

${ }^{31}$ As Cardinal Azzolino stated: 'Cardinale Peretto Sacra Rituum Congregatione examinatis, decretum fuit die 22 Martii 1625 posse si sanctissimo videretur ad specialem Inquisitionem authoritate Apostolica deveniri'; 'Relatio facta per Eminentissimum D. Cardinalem Azzolinum in Congregatione Sac. Rituum habita coram Sanctissimo D.N. die 25. Septembris anni 1663', in Congregatione Sacrorum Rituum sive Eminentissimo, ac Reverendissimo D. Card. Azzolino Limana seu Civitatis Regum Beatificationis, \& Canonizationis Ven. Servae Dei Rosae a Sancta Maria Tertii Ordinis Sancti Dominici. Informatio Super Status, ac Omnibus Hactenus Gestis in Causa pro illius Reassumptione (Rome: Reverendae Camerae Apostolicae, 1664), pp. 24-25 (p. 24), Ref. X2773, Archivum Generale Ordinis Praedicatorum (A.G.O.P), Basilica of Saint Sabina, Rome; hereafter AGOP2773.

${ }^{32}$ ASV1580, fol. 1v; see also Hampe Martínez, Santidad e identidad criolla, p. 21.

${ }^{33}$ For more information on the tripartite structure of the Apostolic Process, see Hart (ed.), Edición crítica del Proceso Apostólico, pp. 28-32. 
as an emissary to ensure their safe arrival to the offices of the Holy See. ${ }^{34}$ The complete file was presented to the Holy See on 21 July 1634, but its arrival proved to be inopportune. Earlier that month - on the $5^{\text {th }}$ to be precise - Pope Urbano VIII had published a decree which prohibited the initiation of proceedings to establish sanctity until 50 years had elapsed since the death of the individual on whose behalf a candidacy was being sought. ${ }^{35}$ Rosa had died only 17 years before and this meant that her file could not be considered until 1667 (ASV1580, fols. 2r-2v).

Rosa's Apostolic Process arrived in Rome at a time when the Papacy was tightening up its control of the practice of canonization. As R. Po-chia Hsia points out: 'The priniciple here was papal control. The Inquisition exercised a strong voice in the debate over sanctity. Under Pope Paul V (1607-21), all saints had first to be pontifically beatified and unauthorized cults repressed, an order affirmed by a 1625 decree of the Holy Office, which removed power from the bishops to promote saints' cults. In 1647, Urban VIII reserved for the first time in the history of the Church the right of recognition of saints only to the papacy'. ${ }^{36}$ Counterbalancing somewhat the exigencies of increased Papal control Rosa's case had royal support. King Philip IV of Spain requested that the Pope, in a letter dated 17 December 1659, 'tuviese por bien de canonizar Rosa de Santa María de la Tercera Orden de Santo Domingo, que murió en la Ciudad de los Reyes de las Provincias del Perú por los buenos informes, que tuve entonces de su ejemplar vida, y singular virtud' ${ }^{37}$ The case for Rosa's canonization was formally re-opened on 25 September 1663 by Cardinal Decio Azzolino (1623-1689). ${ }^{38}$ Post-Tridentine Italy now required updated standards of compliance, and the new spirit of the times was encapsulated in works such as Quaestiones Medico-legales (1621-1651) by the medical scientist, Paulo Zacchia (1584-1673), even while canonic works such as Troilo Malvezzi's Tractatus non infestivus de sanctorum canonizatione (1487) and St Bonaventura's Compendium totius theologiae veritatis (1567) continued to be consulted. ${ }^{39}$ By the mid-1660s when Rosa's virtues and miracles came under scrutiny at the Holy See, the theological landscape had changed dramatically; to use Fernando Vidal's term, a new 'medico-legal economy of miracles' was in operation which was radically different from the less medicalized environment of the 1630s when Rosa's Apostolic Process took place. ${ }^{40}$ Throughout the seventeenth century the Bollandists were introducing more rigorous, text-based and scientific standards into the writing of saints' lives and were, indeed, welcomed by the Pope into the Vatican

\footnotetext{
${ }^{34}$ Two duplicates of the original document, one of 1033 fols. and the other of 914 fols. are kept in ASV, Congr. Riti, 1573 and 1574 respectively; the original letters are included on top of the bound manuscript of ASV1573; some of these letters are quoted in Hampe Martínez, Santidad e identidad criolla, p. 56.

35 'post elapsos ab obitu servi Dei quinquaginta annos'; see Benedictus XIV (Prospero Lamertini), 5 vols., De servorum Dei beatificatione et beatorum canonizatione (Bruxelles: Typis Societatis Belgicae, 1811), vol. I, chap. 22, p. 17.

${ }^{36}$ R. Po-chia Hsia, The World of Catholic Renewal 1540-1770 (Cambridge: Cambridge University Press, 2005), p. 132. See also Peter Burke, 'How to be a Counter-Reformation Saint', in The Historical Anthropology of Early Modern Italy, ed. Peter Burke (Cambridge: Cambridge University Press, 1987), pp. 48-6; and Robert J. Barro, Rchel M. McCleary and Alexander McQuoid, 'The Economics of Sainthood (A Perliminary Investigation)', in The Oxford Handbook of the Economics of Religion, ed. Rachel M. McCleary (New York, NY: Oxford University Press, 2011), pp. 191-215.

${ }^{37}$ Quoted in Michael Lapius Angelus, 'Summarium', Congregatione Sacrorum Rituum sive Eminentissimo, ac Reverendissimo D. Card. Azzolino Limana seu Civitatis Regum Beatificationis, \& Canonizationis Ven. Servae Dei Rosae a Sancta Maria Tertii Ordinis Sancti Dominici. Positio Super Dubio. An Constet de Validate Processus Remissorialis in Specie, \& Testes in eo Sint Rite, ac Recte Examinati (Rome: Reverendae Camerae Apostolicae, 1664), pp. 5-23 (p. 9). Ref. X2772, Archivum Generale Ordinis Praedicatorum (A.G.O.P.), Basilica of Saint Sabina, Rome; hereafter AGOP2772.

38 'Mox vero reassumpta causa in statu, \& terminis in quibus reperiebatur per commissionem manu S.V. signatum die 25 Septembis anni proxime praeteriti 1663 eius Relator deputatus fuit Reverendissimus Cardinalis Azolimus', AGOP2772, p. 2.

${ }^{39}$ Troilo Malvezzi [Troylus Malvetius], Tractatus non infestivus de sanctorum canonizatione (Venice: Franciscus Zilettus, 1487); St Bonaventura, Compendium totius Theologiae Veritatis (Venice: Apud aeredes Melchioris Seffaeim, 1567); Paulo Zacchia, Totius status ecclesiastici proto-medici generalis: Quaestionum Medico-Legalium, Tomus Primus (Lyon: Anisson \& Possuel, 1726). For Zacchia's discussion of miracles, see idem., Book IV, Title I, Questions 1-XI, pp. 281-331. Though the nine books of Zacchia's work were originally published between 1621 and 1651, there were many subsequent editions of his canonic work.

${ }^{40}$ Fernando Vidal, 'Miracles, Science, and Testimony in Post-Tridentine Saint-Making', Science in Context, 20.3 (2007, 481-508 (p. 488).
} 
Library in the early 1660 s. ${ }^{41}$ While in Lima, right up until the seventeenth century, medicine was still viewed 'as being intertwined with the sacred and the miraculous' ${ }^{42}$ in Europe the Council of Trent (1545-1563) had not only ushered in a new 'testimony-based epistemology' but 'medical evidence was given an increased role in evaluating claims of miracles' (Vidal, p. 482). One of the aims of the tightened legislation of the Papacy was to crack down on the proliferation of 'beati moderni' in this period, ${ }^{43}$ and, as we shall see, this had a direct impact on the meandering path taken by Santa Rosa on her journey to sainthood.

Antonio González de Acuña, a professor of moral theology at the University of San Marcos, was in 1659 designated Procurator responsible for presenting the case for Rosa's canonization to the Holy See in Rome, and Cardinal Decio Azzolino was charged with organising the proceedings. Cardinal Azzolino's first action was to draw up a report about whether the Apostolic Process that had taken place in Lima in 1630-1632 had been conducted according to remissorial regulations as mandated by Urban VIII. The result - published in early 1664 - was a report entitled Positio Super Dubio. An Constet de Validate Processus Remissorialis in Specie, \& Testes in eo sint Rite, ac Recte Examinati. ${ }^{44}$ The Devil's Advocate, Petrus Franciscus de Rubeis, in an essay entitled 'Oppositiones R.P.D. Promotoris Fidei. Super Dubio', suggested that there were numerous problems with the way the Apostolic Process had been managed; he argued the apostolic documents should have been submitted within nine months but they were submitted seven years late, he questioned whether those conducting the interrogations were authorized to do so because they were not priests, and also questioned why the deponents had not been required to swear an oath of calumny as was required in all apostolic investigations (AGOP2772, pp. 25-27). These were serious allegations that struck at the very heart of the Apostolic Process as it had been conducted and so - just a few months later - a second report was published entitled Informatio Super status, ac Omnibus Hactenus Gestis in Causa pro illius Reassumptione. ${ }^{45}$ This document contained a list of the 119 miracles due to Rosa's intervention, ${ }^{46}$ a 'Summarium' on Rosa's sanctity and excellent life, this time written in Italian, and all authored by Michael Angelus Lapius, ${ }^{47}$ followed by an 'Animadversiones' written once more by Petrus Franciscus de Rubeis. Cardinal Azzolino commissioned another study - this time from someone who could be argued to be impartial to the process - and this time he asked specifically for the 119 miracles to be examined. Joannes Migetius agreed to take on the task and, in a densely-argued hand-written essay written in Latin in 1665, Migetius provided a summary of the backdrop to the case for Rosa's canonization and then proceeded to dissect all 119 miracles, arguing which could be proposed and which should be rejected. As a result of his analysis Migetius rejected 90 of the miracles and advised that 28 were suitable to be re-examined (ASV1580, fol. 58v). Migetius's criticisms were clearly taken on board by Cardinal Azzolino, along with Antonio González de Acuña and Miguel Angelus Lapius, and a restatement of the case for canonization was made in a subsequent document which was drawn up and printed later on in the same year, entitled Positio Super Dubio An Conste de Septem Miraculis in

\footnotetext{
${ }^{41}$ Hippolyte Delahay, S.J., The Work of the Bollandists Through Three Centuries 1615-1915 (Princeton: Princeton University Press, 1922), esp. pp. 64-71. See also Thomas J. Heffernan, Sacred Biography: Saints and their Biographers in the Middle Ages (Oxford: Oxford University Press, 1988).

${ }^{42}$ Adam Warren, Medicine and Politics in Colonial Peru: Population Growth and the Bourbon Reforms (Pittsburgh: University of Pittsburgh Press, 2010), p. 33.

${ }^{43}$ Clare Copeland, Maria Maddalena de'Pazzi: The Making of a Counter-Reformatoin Saint (Oxford: Oxford University Pres, 2016), pp. 68-71.

44 The title - especially the mention of 'recte examinati' - already gives to understand that Cardinal Azzolino was aware that there were problems with the way in which the Apostolic Process had been handled in Lima in 163032; AGOP2772.

${ }^{45}$ Congregatione Sacrorum Rituum sive Eminentissimo, ac Reverendissimo D. Card. Azzolino Limana seu Civitatis Regum Beatificationis, \& Canonizationis Ven. Servae Dei Rosae a Sancta Maria Tertii Ordinis Sancti Dominici. Informatio Super Status, ac Omnibus Hactenus Gestis in Causa pro illius Reassumptione (Rome: Reverendae Camerae Apostolicae, 1664), Ref. X2773, Archivum Generale Ordinis Praedicatorum (A.G.O.P), Basilica of Saint Sabina, Rome; hereafter AGOP2773.

${ }^{46}$ Michael Angelus Lapius, 'Nota miraculorum', AGOP2773, pp. 18-23. Though written in Latin the names are provided in Spanish in the list.

47 Michael Angelus Lapius, 'Summarium de sanctitate, \& excellentia vitae, ac virtutibus Servae Dei Rosae Sancta Maria', AGOP2773, pp. 1-89.
} 
Vita, \& Sexdecim Post Obitum (1665)..$^{48}$ This published document provides a new description of the case for canonization based on just 23 miracles, consisting of 14 cases of miraculous healing chosen from Migetius's list, as well as some other miracles of phenomenon (such as the Sweating Image of Christ), the amalgamation of other miracles (such as Rosa's visions), and the addition of some new miracles (such as the miracle of the mosquitoes which never bit Rosa, the miracle of the bowing trees and the miraculously sweet odour of her body when it was exhumed three years after her death), as well as two new miracles of healing. The new array of miracles was now divided into two lists, seven of which were proposed to have occurred during her lifetime and 16 after her death. Fierce controversy on the validity of the short list of 23 miracles ensued which, in the main, was related to the accusation that, firstly, the events presented as miracles were not in accord with any of the generic definitions of miracles provided by St Augustine's canonical writings or Paulo Zacchia's Quaestiones Medico-legales and, secondly, there was no evidence of the deponents being questioned on their understanding of what a miracle was. ${ }^{49}$ Valiant counter-arguments were raised by Antonio Gonzalez de Acuña, and the final recommendation of the Sacred Congregation of Rites was that five of the miracles proposed - all of them examples of prophylactic healing - were recommended as worthy to be described as miracles performed though Rosa's intercession. But given the doubts which had been raised about the manner in which Rosa's miracles had been investigated in the Apostolic Process held in Lima in 1630-32, the issue of the need for further corroboration was raised. And it just so happened that - at that very time - news was arriving of Rosa's intervention in miracles which had been occurring in the south of Italy and, thus, a new investigation was born, the Second Apostolic Process of 1670 .

On 4 January 1670 a new Apostolic Process, chaired by the Bishop of Palermo, was set up to investigate miracles which had occurred in Palermo and in Sessa (Aurunca). ${ }^{50}$ The opening statement of the Process demonstrated that the Apostolic Judges were taking care to underline that they would be following the remissorial instructions to the letter. They would specify when and where the interview with the deponent had taken place, provide a record of when the oath was taken, take care that the interview in its totality was transcribed, and they would ask deponents if they used relics related to Rosa (in order to ascertain whether or not Rosa's intervention, and solely hers, had been invoked), ask them what they understood a miracle to be and, once the concession had been granted, if they continued to venerate Rosa; finally the deponents would also be asked some 'devil's advocate questions' such as if there were any other possible reasons or possible natural cause which might explain the cure (ASV2208, fols. 1r-8v). As we can see the remissorial guidelines were to be applied in a stricter way than during the First Apostolic Process; the fact that in the case of both alleged miracles - that relating to Serafino Puglisi (ASV2208, fols. 18v-23v; 14 January 1670) and Angela Cibasa (ASV2208, 44r-51v; 24 April 1670) - the testimony of a professional doctor who gave evidence on the state of the patient before and after the occurrence of the miracle was included in the testimonies demonstrated that the Second Apostolic Process was in conformity with the stricter remissorial guidelines required since Pope Urban VIII's edict, including the use of medical evidence. After Serafino Puglisi's account of his miraculous healing (ASV2208, fols. 18v-23v), depositions were sought from the doctor's assistant, Michel Angelo Muscia (ASV2208, fols. 31v-35v; 10 February 1670), as well as the doctor Isidoro Ballesteros himself (ASV2208, fols. 40r-43v; 22 February 1670), both of whom provided very clear accounts of the illness suffered by the patient (double dose of malignant tertian fever), as well as a description of his state before and after the miracle of Rosa's intervention occurred. Likewise Angela la Cibasa's description of her miraculous healing of a double bout of the same illness (like the previous patient, a double bout of malignant tertian fever) (ASV2208, fols. 44r-

\footnotetext{
${ }^{48}$ Congregatione Sacrorum Rituum sive Eminentissimo, ac Reverendissimo D. Card. Azzolino Limana, seu Civitatis Regum Beatificationis, \& Canonizationis Venerabilis Servae Dei Rosae de Sancta Maria Tertii Ordinis S. Dominici. Positio Super Dubio An Conste de Septem Miraculis in Vita, \& Sexdecim Post Obitum in Casu, \& ad Effectum, de quo Agitur (Rome: Ex Typographia Reverendae Camerae Apostolicae, 1665), 100 pp. Ref: X2775, Archivum Generale Ordinis Praedicatorum (A.G.O.P), Basilica of Saint Sabina, Rome; hereafter AGOP2775.

${ }^{49}$ Petrus Franciscus de Rubeis, 'Oppositiones R.P.D. Promotoris Fidei. Super Dubio. An Constet de Septem Miraculis in Vita, \& Sexdecim Post Obitum in Casu, \& ad Effectum, de quo Agitur', AGOP2775, pp. 53-63.

50 'Rosa a Sancta Maria III Ord. S. Dominici: Supplementa Proc.', 1670, 67 fols, Archivum Secretum Vaticanum, Arch. Congr. SS. Rituum Processus, 2208, fol. 1r; hereafter ASV2208. Sessa, a town in southern Italy, situated between Rome and Naples, is nowadays referred to as Sessa Aurunca, but in the seventeenth-century documents is simply referred to as Sessa.
} 
$51 \mathrm{v} ; 24$ April 1670) is also followed by two witness depositions, one from the doctor's assistant, Giuseppe Casata (ASV2208, fols. 55r-58v, 29 April 1670), and the other from the doctor, Alessio Giarruto (ASV2208, fols. 58v-61v, 30 April 1670), both of which provide a detailed description of the patient's moribund state immediately before the miracle of instantaneous healing occurred as well as a description of the patient's vastly changed health afterwards. The fuller accounts provided on behalf of the two deponents - Serafino Puglisi and Angela Cibasa - were found to be so convincing that they led to the recommendation that these two prophylactic healings were to be understood as miracles. ${ }^{51}$ On 7 October 1670 the results of the Palermo investigation, along with the results of an apostolic investigation carried out in the City of Sessa (Aurunca), were published; the healings of Serafino Puglisi and Angela Cibasa in Palermo and Ioannis Zelilli and Candida Rosetta in Sessa were declared to be miracles. ${ }^{52}$ The five Peruvian miracles (María Sanchez, Isabel Durán, Mauro Diego de Ayala, Doña Magdalena Chamiso, Maria de Vera) were combined with the four Italian ones (Serafino Puglisi, Angela Cibasa, loannis Zelilli and Candida Rosetta) - all of which were examples of postmortem prophylactic healing - and, on 24 August 1617, Rosa de Lima was canonised in St Peter's. ${ }^{53}$

As a result of the tightening of Papal control on the management and decision-making processes involved in canonisation which led to the focus on prophylactic healing as the favoured form of miracle and the need for medical testimonies as evidence to support the case, some of the extraordinary events associated with Rosa - such as the case of the painting of Christ contained in the oratory of Gonzalo de la Maza's residence which, on 15 April 1617, after being implored by Rosa, was seen by numerous witnesses to be 'sweating' profusely, ${ }^{54}$ or Rosa's ability to make flowers grow during the winter as much as during the summer, ${ }^{55}$ or her ability to persuade the mosquitoes in her garden not to bite her, ${ }^{56}$ or her visions of $\mathrm{Christ}^{57}$ - fell outside this Papal jurisdiction. Many of these events of Rosa's life, though denied the status of miraclehood by the Sacred Congregation of Rites, are routinely described in Peru nowadays as 'miracles'. Some of these 'false miracles' were clearly engineered by the misplaced zeal of some of Santa Rosa's modern-day devotees. The 'miracle' of the lemon tree growing in Rosa's garden which was burnt by the Devil because he was annoyed that Santa Rosa was ignoring his temptations is such an example; the visitor who enters Rosa's Santuario is nowadays greeted by a large glass case affixed to the wall of the house containing the scorched remains of one of the lemon-tree branches $!^{58}$ The pamphlet available at the Santuario also refers to two other events as miraculous, that is, Rosa's ability to communicate with mosquitoes and persuade them not to bite her ('Los Mosquitos de Santa Rosa'), and the story of how Rosa advised a cockerel to

\footnotetext{
${ }^{51}$ One other unique characteristic of this case must have swayed the Apostolic Judges to provide a favourable judgement, and this was the fact that the account of Serafino Puglisi's healing contained an unprecedented detail; when Rosa healed Serafino she also spoke to him, with the words: 'lo sono la Rosa, che vengo per rinfrescarti; non dubitare; sta'allegramente; Dio ti vuole un altro poco di tempo nel mondo' (ASV2208, fol. 22r). This is the only occasion in all of the depositions contained in the Ordinary Process as well as the Apostolic Process when Rosa's words to the individual receiving the grace of a miracle were transcribed.

52 'Limana', in AGOP2773, unpaginated band affixed to final page. It is evident that another Process took place to investigate the cases of miraculous healing reported in the town of Sessa (Aurunca), - which led to the confirmation of two other cases of miraculous healing in southern Italy (those pertaining to loannis Zelilli and Candida Rosetta) - but I have been unable to locate these documents either in Peru (they are not in the Archivo Arzobispal de Lima) or in Italy - they are not in the Archivum Secretum Vaticanum or the Archivum Generale Ordinis Praedicatorum (A.G.O.P.)

53 'Limana', in AGOP2773, unpaginated and affixed to final page.

${ }^{54}$ Hart, Santa Rosa de Lima, pp. 298-303. This was the eighth miracle described in the original list of 119; see idem., p. 82.

55 Hart, Santa Rosa de Lima, p. 88; this was miracle 56 in the original list of 119.

${ }^{56}$ This was listed as the third miracle in the reduced list of 23 miracles that were proposed by Antonio González de Acuña and Miguel Angelus Lapius in 1665; see Hart, Santa Rosa de Lima, p. 106.

${ }^{57}$ Rosa's visions were included in the original list of 119 miracles as miracle 62, and in the reduced list of 23 miracles as the second miracle (Hart, Santa Rosa de Lima, p. 89, p. 106).

${ }^{58} \mathrm{~A}$ pamphlet available at the Santuario provides more information about Rosa's miraculous struggle with the devil: 'El demonio que frecuentemente se aparecía a Santa Rosa en horribles figuras, se escondió una vez entre las ramas del limonero para distraerla de sus oraciones y penitencias. Como la Santa no le hacía caso y fracasando en su deseo, se retiró rabioso secando totalmente el árbol que milagrosamente siguió dando frutos. Los devotos fueron arrancando ramas hasta destruirlo, quedando solamente unos troncos como testigos del milagroso hecho'; Santa Rosa de Lima: Vida y Milagros (Lima: Santuario de Santa Rosa de Lima, n.d.), p. 9.
} 
sing when it was under threat of being cooked if it did not sing, and it did ('El Gallito de Santa Rosa'). Neither of these events was deemed a miracle by the Holy See. ${ }^{59}$ Nevertheless the notion that these two events not only happened but were also miracles is remarkably pervasive in Peru. ${ }^{60}$

While the 'false miracles' listed above may be put down to the pueblo's zeal, there are other 'false miracles' that emerged specifically as a result of the time-lag between the publication in 1664 of the first official biography of Santa Rosa de Lima, the Vita mirabilis et mors pretiosa, and the announcement of the final deliberations of the Sacred Congration of Rites, which occurred in October 1670. Because Hansen's biography was published in 1664 - namely six years before the Apostolic Process had been completed - it makes some 'mistakes'; it calls the event in which Rosa made an oil painting of Christ's head 'sweat' a miracle, whereas this event was not deemed to be a miracle by the Sacred Congregation of Rites when it finally published the results of its deliberations. ${ }^{61}$ By including six chapters describing the 'signs, graces and miracles' performed by Rosa - ranging from Rosa's apparition to a number of people after her death to a number of prophylactic healings caused by contact with her body or her image - Hansen's account was in effect attempting to short-circuit the decision-making process of the Sacred Congregation of Rites (Vita mirabilis et mors pretiosa, pp. 287356). While he was not the only contemporary biographer to do this - Giovanni Domenico Lioni's 1665 biography also describes the Sweating Face of Christ as a miracle ${ }^{62}$ - this mistake was more crucial in Hansen's case because of the enormous influence that his biography has had over the centuries.

There is, however, a second reason why the first biography of Santa Rosa de Lima requires further scrutiny and this is because an independent analysis of the evidence available throws into doubt whether Leonardus Hansen was actually the author of this work. Leonardus Hansen has been

${ }^{59}$ Santa Rosa de Lima: Vida y Milagros, between p. 10 and p. 11. These two events are found in the historical record. For information on the mosquitoes, see the Declaration by Doña María de Uzátegui, at fols. 63r-v, in Hart (ed.), Edición crítica del Proceso Apostólico, p. 118. For information on the cockerel, it should be noted that it was a 'pollito' not a 'gallito'; see the Declaration in the Apostolic Process provided by Santa Rosa's mother at fols. 181v-82v, in Hart (ed.), Edición crítica del Proceso Apostólico, p. 202. The saving of the cockerel was not proposed on any occasion to the Congregation of Sacred Rites as a potential miracle, but the ability to communicate with mosquitoes was (it was the third miracle of the 23 submitted in 1665; see Hart, Santa Rosa de Lima, p. 106), but it was rejected. Just as important, of course, was the enormous spiritual impact Rosa had on her hijas espirituales; for an excellent discussion of this impact, see Nancy E. Van Deusen, 'Rosa de Lima and the Imitatio Morum', in Embodying the Sacred: Women Mystics in Seventeenth-Century Lima (Durham, NC: Duke Univeristy Press, 2018), pp. 23-46.

${ }^{60}$ The answer to one of the questions in the questionnaire I circulated to a number of individuals who had read my biography of Santa Rosa (the question was 'Has the reading of this book changed your opinon about Santa Rosa?') was that the reading had changed his/her view because it had led to a new awareness of 'milagros increíbles como los realizados con las personas desahuciadas. Yo me había quedado con los relatos de los mosquitos y del gallo'; 'Breve cuestionario sobre Santa Rosa de Lima de Lima: 8 de abril de 2018'. I should add that the respondent was not the only person to have made this comment about the miracles; I heard it from countless other individuals I interviewed informally in Lima. It should also be noted that the remarkable persistence of these types of popular miracle are not restricted to Peru; on 10 August 2018 I visited the Parroquia de Santa Rosa de Lima, Xochiac, in Mexico City, and was advised to visit a nearby shrine dedicated to the Virgen Guadalupe in the garden of which there was an enormous blue stone inscribed with the following message: '1965 - Esta piedra fue movida una manana espledorosa con la ayuda de los brazos de Santa Rosa [--] perdurará la emosión (sic) al recordarlo [--] las bellas flores armonisando (sic) se combinan, combinan con el majestuoso paisaje y el arte de quienes conservan el natural follaje que se encuentra en el selecto jardín delicado perfume de jazmín'; for further information on Santa Rosa's uncanny association with heavy objects, see the description of Rosa's experience of becoming as heavy as a stone when she attempted to leave her mother and join a convent; Hart, Santa Rosa de Lima, pp. 196-99. For the discussion of local religious cults which have similar characteristics to these, see William A. Christian, Local Religion in Sixteenth-Century Spain (Princeton: Princeton Univeristy Press, 1989).

${ }^{61}$ The title of chapter XIX, which describes this event, is 'Rosa, ut Christum omnibus amandum persuadeat, manifestum sudantis Imaginis miraculum impetrat'; see Hansen, Vita mirabiliis et mors pretiosa, pp. 147-54.

62 See Giovanni Domenico Lioni, Breve Ristretto della Vita Meravigliosa della Venerabil Serva di Dio, Suor Rosa di S. Maria Da Lima del Perù nell'America Meridionale, Religiosa del Terzo Ordine di S. Domenico (Rome: Nicol Angelo Tinassi, 1665), pp. 136-44), and particularly his comment 'non vi restò più luogo alcuno di dubitar del miraculo' about the sweating head of Christ, p. 137; see also pp. 242-46; pp. 248-50. 
assumed, until now, by practically everybody to have been a German Dominican priest. Luis Millones, for example, refers to him as 'el dominicano alemán', as does Ramón Mujica Puntilla ('el biógrafo dominico alemán'). ${ }^{63}$ Graziano likewise describes Hansen as 'Rose's principal hagiographer' and as a 'German Dominican', ${ }^{4}$ and Ann W. Astell suggests that Leonard Hansen 'taught theology in Vienna, Austria, in 1638, before being transferred to Rome'. ${ }^{65}$ There are some references to Leonardus Hansen in the canonic histories of the Dominican Order. Angelus Maria Walz, O.P., in section 61 ('Procurator ordinis socii et alii officiales') of his Compendium historiae ordinis praedicatorum (1930), refers to Hansen as a German friar: 'dum ad utilitatem provinciarium borealium ab insulis britanicis per Germanias usque ad Russiam se extentium modo fratres Teutoniae ut Leonardus Hansen, modo Austriaci ut Raymundus Fitzing, modo Bohemi ut Emericus Langenwalter (per annos viginti)'. ${ }^{66}$ But, as we shall see, the description of Leonardus Hansen as a German Dominican - despite his very Germansounding name - is highly problematic.

There are, first of all, a number of inconsistencies subtending the notion that Leonardus Hansen was the author of the Vita mirabilis et mors pretiosa. The source used by Angelus Maria Walz to substantiate his statement that Hansen was a German Dominican is the first edition of J. Quétif and J. Echard's 2-volume work, Scriptores Ordinis Fratrum Preciatorum Recensiti (1719-1721); there are three references to Leonardus Hansen in vol. II of that work. ${ }^{67}$ The first alludes to the abbreviated version of Hansen's 1664 biography that F. Antonio González de Acuña published a year later in $1665,{ }^{68}$ while the second refers to the publication of Santa Rosa's biography in Latin, and it unfortunately misquotes the title of the work, and does not mention Hansen as the author. ${ }^{69}$ Of the three references clearly the biographical entry is the most important and, despite its length, it is worth quoting the entry relating to Leonardus Hansen's life in full:

F. Leonardus Hansen Teuto Juliaci natus, Coloniae vero adolescens ad ordinem ascitus per gradus omnes magisterium ascendit, theologiam Viennae Austriae publice docebat anno MDCXXXIII, exinde pluries in comitiis ordinis Romae pro sua Teutoniae provincia diffinitor generalis missus annis MDCXLIV \& MDCLVI, quem tum ab egregias dotes, studium praesertim

\footnotetext{
63 Luis Millones (ed.), Una partecita del cielo: la vida de Santa Rosa de Lima narrada por Gonzalo de la Maza a quien ella llamaba padre (Lima: Editorial Horizonte, 1993); Ramón Mujica Puntilla, Rosa limensis: mística, política e iconografía en torno a la patrona de América (Mexico City: Fondo de Cultura Económica, 2005), $2^{\text {nd }}$ ed., p. 42, n. 1. See also Hugo Rueda Ramírez who, in his study, 'Leer a Santa Rosa: propuesta de condificación lingüística y visual en la operación que construye la figura de Santa Rosa de Lima', Cyber Humanitatis, Universidad de Chile, makes a similar statement.

${ }^{64}$ Frank Graziano, Wounds of Love: The Mystical Marriage of Saint Rose of Lima (New York: Oxford University Press, 2004), p. 4.

${ }^{65}$ Ann W. Astell, Eating Beauty: The Eucharist and the Spiritual Arts of the Middle Ages (Cornell: Cornell University Press, 2006), p. 172, n171. F.M. Capes, in his biography of Santa Rosa, refers to one of his sources the Latin biography, as 'by F. Leonard Hansen, a German Dominican'; The Flower of the New World: A Short History of St Rose of Lima (London: Washbourne, 1899), p. xxi.

${ }^{66}$ Angelus Maria Walz O.P., Compendium historiae ordinis praedicatorum (Rome: Herder, 1930), p. 291. Hansen is also referred to in the same volume as the author of the biography of Santa Rosa: 'S. Rosae Limanae auctore Leonardo Hansen (p. 345). This, incidentally, must be the source used by Domingo Ángulo in his description of Hansen's ecclesiastical career although - curiously - he does not provide details of that source; see Ángulo, pp. 79-80.

${ }^{67}$ Full reference is Scriptores ordinis praedicatorum recensiti, notisque historicis et criticis illustrati opus quo singularum vita, praeclareque gesta referuntur... , inchoavit R.P.F Jacobus Quétif S.T.P. absolvit R.P.F. Jacobus Echard, 2 vols (Paris: J.B. Christophorum Ballard, 1719-1721). The three references are in vol. II, p. 705, p. 702, and p. 692.

68 The text is listed as Compendium mirabilis vita Rosa de S. Maria Limana ordinis S. Dominici, ex prolixiori vita a F. Leonardo Hansen; see Scriptores ordinis praedicatorum recensiti, notisque historicis et criticis illustrati opus quo singularum vita, praeclareque gesta referuntur... , inchoavit R.P.F Jacobus Quétif S.T.P. absolvit R.P.F. Jacobus Echard, 2 vols (Paris: J.B. Christophorum Ballard, 1719-1721), vol. II, p. 692. The copy of this 1665 text that I consulted at the AGOP has a different title; see footnote 3.

${ }^{69}$ The text is listed as Vita S. Rosae ex SS. patribus \& historiis Ecclesiasticis illustrata; see Scriptores ordinis praedicatorum recensiti, notisque historicis et criticis illustrati opus quo singularum vita, praeclareque gesta referuntur... , inchoavit R.P.F Jacobus Quétif S.T.P. absolvit R.P.F. Jacobus Echard, 2 vols (Paris: J.B. Christophorum Ballard, 1719-1721), vol. II, p. 692.
} 
regularis disciplinae, ac eximiam pietatem socium pro provinciis Germanis allegit sibi magister ordinis F. Jo. Bapt. de Marinis, ac paucis post annis provincialis Angliae titulo decoravit. Ea ratione in electione duorum ordinis magistrorum sequentium F. Jo Thomae de Rocaberti, \& F. Antonii de Monroy annis MDCLXX \& LXXVII Romae votum tulit, apud quos eodem focii munere functus, eademque in existimatione habitus est. Vir non eruditione tantum sed mira humillitate conspicuus, omnium sibi conciliabat affectum: solitudinis amans semper aut legebat aut scribebat aut orebat: donec annis gravis, integro ad ultimam usque horam sensu cum virtutum odore piam Deo rediddit animam XXVIII martii MDCLXXXV, aetatis LXXXII in S. Mariae super Minervam sepultus. In lucem quaedam dedit opera quae sequuntur. 1. Vita mirabilis et mors pretiosa venerabilis sororis Rosa de S. Maria Limensis ex tertio ordine S.P. Dominici, Romae, Nic. Angeli Tinassi 1664 in 12 pagg. 452; ibidem eodem anno in 4 pp. 360. Extat haec Parisiis in Regia H 1717, illa apud nostros ad S. Honorati. Eadem Romae apud eumdem 1680 in fol. Extat Romae in Casanatensi. 2. Officia plura Nominis Jesu, Nominis Mariae, B. Pii V, B. Ludovici Bertrandi, quae aliquandiu in usu apud nos fuerunt. Breviariis inserta, sed postea suppressa. 3. Praeluserat alias $\&$ gratulatus erat metrice epigrammatibus septem vario carminum genere, sed $\&$ in Marcum de Dominis stylum intorferat $\&$ acumen initio opusculi F. Dominici Gravina ordin. Praed. Pro sacro ordinis sacramento iterates typis, Coloniae Agripp. Henrici Kraft 1638 in 4, sed tum rudiori stylo. ${ }^{70}$

At first glance - mainly as a result of the dates it provides for Hansen's public teaching in Vienna in Austria (1633), his trips to Rome (1644 and 1646), his character (he loved solitude, and spent a great deal of time either reading or writing or praying) - the entry provides a convincing biographical summary of an individual's life. But if we drill down into the details provided, some internal inconsistencies emerge:

\footnotetext{
70 'Father Leonard Hansen, a German born in the Julian Alps, grew up in Cologne and, when admitted to the [Dominican] Order, passed all the grades of the Office of Master, and he was publicly teaching theology in Vienna, Austria, in 1633, and subsequently, as the General Regulator of the various Orders of Rome with which he was involved, he was sent out in 1644 and 1656 as a member and representative of the German Provinces and, as a result of his exceptional talent for study and especially his aptitude for regular self-discipline along with his outstanding piety, he was elected as Master of the Order of John the Baptist of Marinis, and only a few years later he was awarded the title of Provincial of England. For that reason he was elected to the Teaching Fellowship of the following two orders, the Order of John Thomas of Rocaberti in 1670 and the Order of Antony of Monroy in 1677. He took his vows in Rome, and in each of these orders he performed the same duties and in both he also enjoyed the same high reputation. He was a man who was conspicuous not so much for his erudition as for his remarkable humility, and he was able to bring all men together through his love of others; a lover of solitude he spent his time either reading or writing or praying: then in his later years, with all his faculties intact until his last hour, and living as a saint in great virtue, he returned his soul to God on 28 March 1685, and at the age of 82 years he was buried in the Church of Santa Maria Sopra Minerva. During his life he wrote the following works: 1. Vita mirabilis et mors pretiosa venerabilis sororis Rosa de S. Maria Limensis ex tertio ordine S.P. Dominici, Rome, Nic. Angeli Tinassi 1664, 452 pp.; the same work was published four years later, now with 360 pp. There was also a Paris edition, Regia, of 1717, published by the Dominican Order, and another published in Rome by Casanatensi in 1680. 2. Many Orders of Service in Jesus' name and in Mary's name, and B. Pii V., and B. Ludovici Bertrandi, which were used in our community for an extended period of time. They were interpolated into our breviaries, but were subsequently suppressed. 3 . He stood out for some other works and was much praised as an author of seven songs of various types and composed in epigrammatic metre, though the style and wit characteristic of the early part of the pamphlet, published in movable type by the Dominican Order of Gravina (Coloniae Agripp., Henry Kraft, 1638) was interrupted by a more coarse style redolent of Marco [Antonio] de Dominis'; see Scriptores ordinis praedicatorum recensiti, notisque historicis et criticis illustrati opus quo singularum vita, praeclareque gesta referuntur... , inchoavit R.P.F Jacobus Quétif S.T.P. absolvit R.P.F. Jacobus Echard, 2 vols (Paris: J.B. Christophorum Ballard, 1719-1721), vol. II, p. 705. The reference to other works written by Leonard Hansen such as the Orders of Service and the 'seven songs' are so vague as to be fictitious. The reference to the seven songs written in the style of Marco Antonio de Dominis (1560-1624), given that De Dominis was an Anglican who attacked the Papacy (1616-1621) only to subsequently recant his Anglicanism and return to Rome (which he did in 1622) is surely a tongue-in-cheek reference to the real author of the Vita mirabilis et mors pretiosa, an English Catholic who had a highly tempestuous relationship with England, as we shall see.
} 
(i) if Leonardus Hansen preached in Vienna in 1633 ('Viennae Austriae publice docebat anno MDCXXXIII') why is there no independent corroboration of this? ${ }^{71}$

(ii) if Leonardus Hansen was decorated ('decoravit') for his service in England, why is there no mention of this fact in any of the historians of the English Dominicans? ${ }^{72}$

(iii) if Leonardus Hansen had been buried in the Saint Mary above Minerva Church in Rome ('in S. Mariae super Minervam sepultus', as the 1719-1721 entry suggests), why is there no tomb? ${ }^{73}$

(iv) Finally, why, in the second edition of the above-quoted compendium of Dominican writers is all reference to Leonardus Hansen removed ${ }^{74}$

71 The list of members of the Austrian Dominican Order provided in Sebastian Brunner's Der Prediger-Orden in Wien und Oesterreich (1867) has no reference, for example, to one Leonardus Hansen. See the list of 178 Austrian Dominicans who lived during the period 1309-1863, in Sebastian Brunner, Der Prediger-Orden in Wien und Oesterreich. Regesten, Collectaneen, Nekrologien, Epitahien, Universitäts-Angelegenheiten, Profess- und Bruderschaftbücher, Biographische und Historische Skissen. Aus Archivalischen Bisher Unedirten Handschriften Mitgetheilt (Wien: Wilhelm Braumüller, 1867), pp. 42-47. The archives consulted by Brunner are extensive, and listed at pp. iii-iv. There are no references either to Hansen in the chronology of the Dominican Church events in Vienna pertaining to the year 1633 (Brunner, p. 19), as mentioned in Quétif and Echard's account. Even when Brunner describes the celebrations in Vienna to mark Rosa's beatification, which occurred on 15 April 1668 ('Anno domini celebravimus ex mandato Rmi P. Magistri Generalis F. Joannis Baptistae de Marinis festum B. Rosae a S. Maria Ord. Praed. Tertiae Regulae: quae fuit 15. Aprilis ejusdem anni a Summo Pontificae S.S. Nostro Papa Clemente IX. In numerum Beatarum relata, summo totius populi Romani applausu et concursu'; Brunner, pp. 20-21), there is no mention of Hansen, which is odd given that he ostensibly was the author of the biography of her life - published only 4 years before in 1664 - which played such an important role in the beatification process. The account mentions that a second more formal service in Rosa's honour was held in Vienna in June, which was extremely well-attended: 'per totam vero septimanam fuit tantus concursus populi, praesertim nobilitatis, ut devotio describi non possit, praecipue propter quotidianam Panegyrim, quae per varias Ordinum conciones, non tam laudabiliter, quam mirabiliter de B. Rosa dicta sunt' (Brunner, p. 21). Once more there is no mention of Hansen.

72 Neither Raymond Palmer O.P., in his Obituary Notices of the Friar-Preachers, or Dominicans, of the English Province, from the Year of our Lord 1650, compiled from the Archives of the Master-General of the Dominican Order at Rome, and from the Records of the Province (London: Burns \& Oates, 1884), nor B. Bede Jarrett, in his The English Dominicans, revised by Walter Gumbley (London: Burns Oates, 1937), nor Walter Gumbley in his Obituary Notices of the English Dominicans from 1555 to 1952 (London: BlackFriar Publications, 1955), or William A. Hinnebusch O.P., in The Dominicans: A Short History (Staten Island, NY: Dominican Publications, 1985), mention such an honour being bestowed on an individual by the name of Leonardus Hansen.

${ }^{73}$ St Catherine of Siena is buried there, there is a chapel devoted to Santa Rosa, there are a number of popes and cardinals buried there, but no-one by the name of Leonardus Hansen buried there. I made a physical inspection of the Basilica di Santa Maria Sopra Minerva in Rome on 3 February 2014, and again on 20-21 May 2015. I also consulted the following internal documents of the Basilica: 'Le tombe della Minerva da un documento anteriore al 1845' ( 2 fols; 75 entries) and 'Sepolture e lapidi sepolcrali esistenti in Basilica' ( 13 fols; 214 entries). In the first list there are 13 Dominicans, and none with the name of Leonardus Hansen; the second list contains six Dominicans but again Leonardus Hansen does not appear. Leonardus Hansen was not buried in the Basilica di Santa Maria Sopra Minerva. His body is not there, and I believe there is enough evidence to suggest he is a fiction. The chapel dedicated to Santa Rosa (the Colonna Chapel) does have a tomb inside but it is of Isabella Alvarez de Toledo; see Anonymous, La Basilica di Santa Maria Sopra Minerva (Rome: Piazza della Minerva, 2001), p. 7. Originally built in the $15^{\text {th }}$ century, the chapel was dedicated to Santa Rosa as a result of her canonization in 1671. The re-vamping of the chapel was overseen by Antonio González de Acuña who was in Rome at the time. A painting by Lazzaro Baldi (1623-1703) was placed on the altar in St Peter's Church during the canonization ceremony, and now hangs over the altar in the Colonna Chapel in the Basilica di Santa Maria Sopra Minerva. I record my thanks to the archivist of the Archivum Provinciae Romanae S. Catherinae Senensis Archivum Minervitanum, Dr Fabiana Spinella, for all her help provided on 21-22 May 2015 on the history of the S. Rosa da Lima chapel as well as providing lists of the individuals buried in the Basilica. Likewise there is no mention of Leonardo Hansen in the records - which date back to the sixteenth century - of the Saint Rosario Confraternity associated with the Maria Sopra Minerva Church. See Elena Lisi, 'Inventario dell'Archivio della Cofraternità del SS. Rosario in Maria Sopra Minerva conservato nell'Archivio di Stato de Roma', submitted as a thesis in Archives and Librarianship at the 'Tor Vergata' Studies University of Rome, 2010-2011; Archivio di Stato di Roma, 401.

${ }^{74}$ The exact title of the second edition is Scriptores Ordinis Fratrum Prediciatorum Recensiti. Notis historicis et criticis illustrati ad annum 1700 autoribus Fr. Jacobus Quétif et Fr. Jacobo Echard. Ab anno autem 1701 ad annum 1750 producti cura et labore PP. Remigii Coulon et Antonini Papillon (Rome: 1916), 2 vols. Leonardus Hansen does not have an entry as an author of the period covered by the book (1600-1750), neither is he listed in the index (vol II, pp. 884-88), nor is he cited in any of the entries dedicated to writers and critics of the period. The 
Taken separately, these anomalies might not have raised any suspicions about the accuracy of Quétif and Echard's biographical entry. But - when combined - they are sufficient to allow us to question if the entry for Leonardus Hansen which appeared in the second volume of the 1719-1721 edition of the Scriptores Ordinis Fratrum Praedicatorum Recensiti is true.

So, if the author was not a German-speaking Dominican, who was he? If we look more closely once more at the frontispiece of the 1664 editio princeps, as well as the second edition of the book published in 1668, the author is clearly referred to as an English Dominican: 'P.F. Leonardum Hansen S. Th. Magist. Provincialem Angliae, \& Socium Reverendissimi P. Magist. Generalis Ord. Praed'.

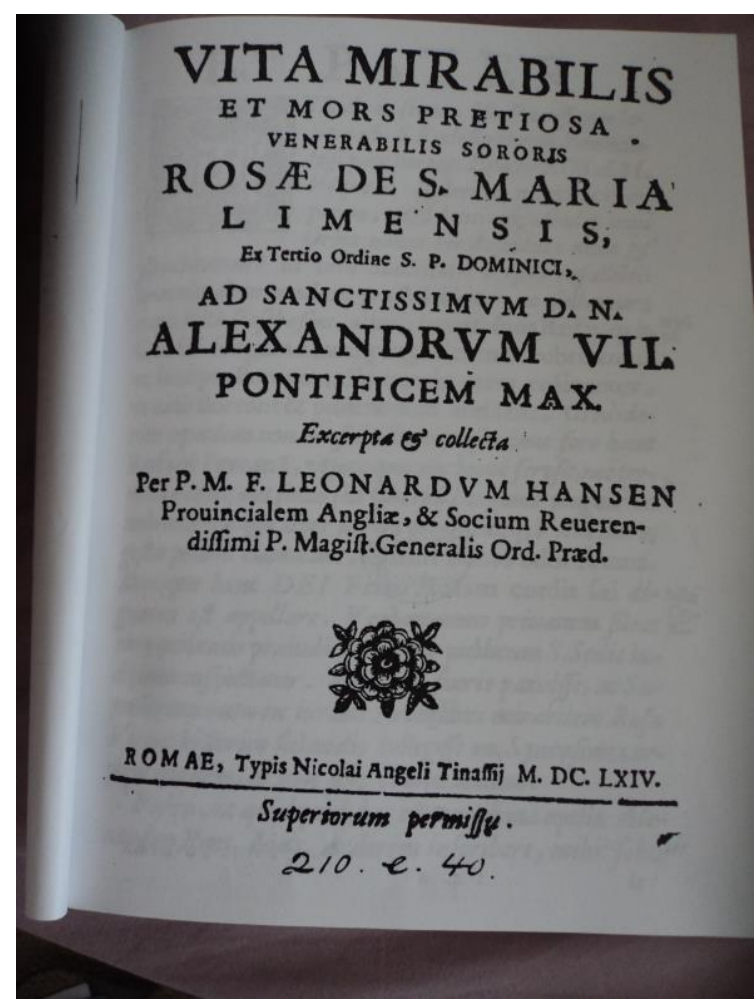

Figure 1: Frontispiece of the 1664 editio princeps of Leonardus Hansen's Vita mirabilis et mors pretiosa

Kathleen Ann Myers appears to favour the hypothesis that Hansen was English. She states: 'The influential English Dominican, Leonard Hansen, was asked in 1664 to write a biography of Rosa. His four-hundred-page Latin text, Vita Mirabilis Mors Pretiosa Venerabilis Sororis Rosa de S. Maria, became the most successful hagiography of her life. Written by someone who never knew her, the account, which drew on the two procesos, nonetheless offers a compelling portrait of Rosa as the Catherine of Siena of the New World' ${ }^{75}$ However, as mentioned above, none of the historians of English Dominicanism, neither Raymond Palmer, nor Bede Jarrett, nor Walter Gumbley nor William Hinnebusch, mention an English Dominican called Leonardus (or Leonard) Hansen.

If, however, we pursue the hypothesis that the author of the Vita mirabilis et mors pretiosa was English, what ensues? The first edition of the Vita mirabilis et mors pretiosa was published in Rome in 1664 but the second edition was published in Louvain, Belgium, in $1668 .{ }^{76}$ Louvain was, in the

curious impression given by this second, expanded and corrected edition of the Scriptores Ordinis Fratrum Praedicatorum Recensiti is that Leonardus Hansen has been airbrushed out of Dominican history. There are, perplexingly, no references in the second edition as to why this should have occurred.

${ }^{75}$ Kathleen Ann Myers, Neither Saints nor Sinners: Writing the Lives of Women in Spanish America (Oxford: Oxford University Press, 2003), p. 29.

${ }^{76}$ Complementing this thesis is the fact that a Theological College of St Thomas functioned in Louvain from 1695 until 1794, i.e. was established a few decades after the publication of the Latin biography of Santa Rosa de Lima. 
sixteenth and seventeenth centuries, a focus of Tridentine Catholicism and offered a haven of respite for Catholics forced into exile from England and Ireland. ${ }^{77}$ One hypothesis might be that Leonardus Hansen was an English Dominican who had been forced to live in Europe given the persecution that the Dominicans, or Black Friars as they were known in England, suffered during the seventeenth century. William A. Hinnebusch gives some examples of the persecution suffered:

All during the century, the friars of Ireland, Scotland and England suffered harrasment, imprisonment and sometimes death. The Irish province offered a holocaust of over 100 martyrs and many deportees. Some English friars spent long years in prison. Venerable Robert Nutter was hanged, drawn and quartered at Lancaster in 1600. David Joseph Kemeys died in Newgate prison, London, in 1680, and Patrick Primrose paid for his zeal by death in a Scottish prison in $1670 .^{78}$

The publication of the Vita mirabilis et mors pretiosa in 1664 and 1668 coincided with this period of persecution of English Dominicans, and a plausible hypothesis would be that, since Leonardus Hansen did not exist, his name could have been a pseudonym designed to hide his true identity. Are there any precedents for the practice of using pseudonyms in England during this period? Indeed there were: Thomas Middleton (1622-55) had an alias, Dade. ${ }^{79}$ And a potted history of the life of the most famous English Dominican of the time suggests why this was so. Thomas Howard (1661-1675) was prior of Bornem (originally Bornhem, in Belgium), and appointed vicar on 24 July 1661 . He was often absent from the priory in England and, in 1665, he was appointed almoner and principal chaplain to Queen Catherine, wife of Charles II. That the biography of Rosa's life was going to be used by the Catholic hierarchy in an attempt to curb the spread of Protestantism in England is suggested vividly by the fact that the second edition of the Portuguese translation of her biography was dedicated to none other than Queen Catherine of Braganza. ${ }^{80}$ The author of what was, with hindsight, clearly a biographie à clé was Souza de Macedo who - as a result of the war of secession in Portugal - had been sent in 1640 as secretary of the Portuguese Embassy to England during John IV's reign and then, ten years later, to Holland, in order to return to Portugal in 1663 (Ángulo, pp. 99-100), was no stranger to the politics of religion during this troubled period of the seventeenth century.

On 27 April 1672 the Holy See appointed Thomas Howard Vicar Apostolic of all England, but the English government found out about the appointment and eventually, at the request of Charles II who, though on friendly terms personally with Thomas Howard, feared the nomination would stoke up anti-Catholic sentiment, and Rome eventually withdrew the appointment (Gumbley, pp. 9-10). Two years later, though, in 1674, seemingly not having learned his lesson, Thomas Howard received into the Church a minor canon of Windsor - which at the time was a capital crime, and he was discovered and had to return immediately to Bornem. Thomas Howard's experience demonstrates clearly the level of anti-Catholic sentiment which existed in England in the 1660s and 1670s, which forced individuals to conceal their true identity, and particularly if they had a strong allegiance with Rome.

If one works from the hypothesis that the author of Vita mirabilis et mors pretiosa was an English Dominican who used a pseudonym for fear of persecution then a set of likely culprits would be those ten individual Dominicans who - in 1678, that is, ten years after the second edition of the Vita mirabilis et mors pretiosa came out - were accused of being Catholic conspirators by Titus Oates. ${ }^{81}$

\footnotetext{
${ }_{77}$ R. Po-chia Hsia, The World of Catholic Renewal 1540-1770, pp. 82-95, esp. p. 90.

78 William A. Hinnebusch O.P., The Dominicans: A Short History (Staten Island, NY: Dominican Publications, 1985), p. 135.

${ }^{79}$ B. Bede Jarrett, The English Dominicans, revised by Walter Gumbley (London: Burns Oates, 1937), p. 184.

${ }^{80}$ Epitome panegyrico de la vida admirable y muerte gloriosa de S. Rosa de Santa Maria, virgin dominicana, A la Serenissima Princesa D. Catalina Reyna de Gran Bretaña (Lisbon: Officina de Antonio Craesbeeck de Melio, 1670; see Domingo Ángulo, p. 99.

${ }^{81}$ It might be argued that I have focussed unfairly on only 10 of the total Dominican population at that time, but it should be added that there were only thirty-eight English Dominicans during this period: 'At this period the English Dominicans numbered thirty-eight and were distributed between the various missions in England and
} 
When the latter, on 31 October 1678, was questioned on oath in the House of Lords about his accusation, he named more than 80 priests who were, in his view, engaged in a plot to bring down the British monarchy; of these 43 were Jesuits, ten were Dominicans, three were Carmelites and two Franciscans. ${ }^{82}$ The ten Dominicans were Thomas Howard, Vincent Torre, Albert Anderson alias Munson, David Joseph Kemeys, Dominic Maguire, William Collins, Thomas Fidden, Vincent Hyacinth Cowper, Alexander Lumsden and Edward Bing (Palmer, The Life of Philip Thomas Howard, p. 183). Oates swore - and this was only one of his many perjuries, not for nothing did he become known as England's greatest perjurer - that all of the dominions of the King of England were to be given to Catholics.

Oates declared that Innocent had issued a bull dated either the November or December before (i.e. 1677), a copy of which had been shown to him, whereby the pope was pleased to dispose of the bishoprics of England. Of these twenty sees, five were to go to the Dominicans, five to Jesuits, two to Franciscans, one to a Benedictine, and the rest to secular clergy. The archbishopric of Canterbury was given to Cardinal Howard, with an augmentation of forty thousand crowns a year to maintain his legative authority; Ely to Vincent, Provincial of the Dominicans; Peterborough to Gifford a Dominican; Bristol to Minison [Munson] a Dominican, and Bangor to Joseph David Keimash, a Dominican (Palmer, p. 184). When the 'plot' was discovered, Vincent Torre's reaction was that of someone whose cover had been blown. Raymond Palmer describes what happened subsequently: 'Of the Dominican "traitors" five were arrested, two were beyond the jurisdiction of the Houses, one fled the country, one escaped being taken, and one died amidst the troubles' (Palmer, The Life of Philip Thomas Howard, p. 184). Vincent Torre was the individual who 'fled the country'; he escaped to Bornhem. Notice also that the only conspirator named as a 'Provincial' by the prosecution was Torre himself; as Palmer clarifies, Vincent Torre was 'commonly called Provincial of the Dominicans in England' ${ }^{83}$ Given that the author of the Vita mirabilis et mors pretiosa is described as 'S. Th. Magist. Provincialem Angliae, \& Socium Reverendissimi P. Magist. Generalis Ord. Praed.' in the 1664 editio princeps, this suggests that Vincent Torre is a strong contender as the English Dominican behind the pseudonym of Leonardus Hansen.

Raymond Palmer provides the following short description of Vincent Torre's career:

1687. Aug. 24 $4^{\text {th }}$. Very Reverend F. Vincent Torre. S. Th. Mag. English Pr. 1652, at Dinan, France. Master of Novices at Marlaix, Bretagne, 1657. Went to Bornhem, Aug. 1658. Master of Novices at Gradi, Viterbo, 1659, and at Bornhem, being sent back May $5^{\text {th }}, 1660$. Made Sub-prior, Sept $8^{\text {th }}, 1663$. In London, 1666. Confessor to the Sisters at Brussels 1674. Instituted Vicar-General, Jan $23^{\text {rd }}, 1676$. Again in London. Implicated by Oates, as a conspirator designed for bishopric of Ely. Fled to Bornhem, and in 1682, made Superior. Quitted, August $20^{\text {th }}, 1683$, for SS. Giovanni e Paolo. Instituted, 1685, the first Provincial since the fall of religion in England, and received his degree. Assisted in the General Chapter of the Order, at Rome, June 1686. Appointed, Feb $9^{\text {th }}, 1687$, Commissary of the Master-General for a visitation of the English Province; arrived at Bornhem Aug $3^{\text {rd }}$ and d. there, aet 57 , prof. 36 , sac. $33 .^{84}$

Note that, in two further respects (i.e. as well as being the 'Provincial' of the English Province) - in being 'Very Reverend' and possessing a Masters degree in Sacred Theology (S. Th. Mag.) - Vincent Torre matches exactly the qualifications and attributes which are used to describe Leonardus Hansen in the 1664 frontispiece of Vita mirabilis et mors pretiosa.

their three houses on the Continent'; the ten mentioned were clearly the most prominent of the thirty-eight; see Bede Jarrett, p. 164.

${ }^{82}$ Raymond Palmer, O.P., The Life of Philip Thomas Howard, O.P., Cardinal of Norfolk (London: Thomas Richardson and Son, 1867), pp. 182-83.

83 Palmer, The Life of Philip Thomas Howard, p. 184. It should also be noted that, on 15 November 1681, the government of the Community in England was committed to Vincent Torre; see Palmer, 'In Exile, Part l', in Palmer, Dominicana (n.d., excerpts of essays held in the Archives at Douai Abbey), pp. 581-602 (p. 602). ${ }^{84}$ Raymond Palmer, O.P., Obituary Notices of the Friar-Preachers, or Dominicans, of the English Province, from the Year of our Lord 1650, compiled from the Archives of the Master-General of the Dominican Order at Rome, and from the Records of the Province (London: Burns \& Oates, 1884), p. 4. 
There are four other facts that offer further weight to the hypothesis that the man behind Leonardus Hansen's mask was Vincent Torre. The first is that the Very Reverend F. Vincent Torre, Provincial (1631-1687), was of Spanish origin - he was said to have been a member of the ancient family of the same name which had originally moved from Spain to Warwickshire and then, in the fifteenth century, had moved to Lincolnshire - and thus, unlike the other nine Dominican conspirators - was fluent in Spanish and would have been able to read the beatification and canonization documents with ease (Bede Jarrett, p. 164). Secondly, Vincent Torre was in Rome for a period of years before the Latin biography was published (1664); he left Bornhem to go to Rome - on behalf of Thomas Howard who was too busy with other matters - on 10 October 1658 and took up a teaching position there; he was a lector in philosophy and theology at Viterbo (Palmer, The Life of Philip Thomas Howard, p. 108). Thirdly, the companion he took with him was a master of disguise and this may well have enhanced Vincent Torre's awareness of the importance of using dissemblement for the purpose of selfprotection. As Palmer suggests: 'He had along with him Brother Francis Hayes an Englishman who shortly before had received the laybrother's habit in the convent. This Hayes was clever in several languages, and was for some years with the English Franciscans at Douay as their steward or procurator; in times of war he dressed like a hermit and cultivated his beard for more conveniently discharging his office in disguise' (Raymond Palmer, The Life of Philip Thomas Howard, p. 108). Fourthly - and perhaps most important of all - unlike the mild-mannered, anti-intellectual figure cut by the Leonardus Hansen created in the entry in the 1719-21 edition of the Scriptores Ordinis Fratrum Praedicatorum Recensiti ('Vir non eruditione tantum sed mira humillitate conspicuus') Vincent Torre was a fierce intellectual and an inflexible disciplinarian, ${ }^{85}$ much more the type of individual who would have admired Rosa's toughness and resilence, and seen her crown as 'fecund' as a result of its capacity to inflict pain: 'fecunda corona, aculeis nonaginta \& novem armata' ('a fecund crown armed with ninety-nine spikes'; Vita mirabiliis et mors pretiosa, p. 51).

There is, thus, enough circumstantial evidence to propose that the author of the biography in Latin of Santa Rosa, Vita mirabilis et mors pretiosa was the English Dominican, F. Vincent Torre (1631-1687). ${ }^{86}$ What is most curious about this episode is that it shows that Santa Rosa's biography became part of a game of now-you-see-me-now-you-don't between the Holy See and England, with the Dominicans acting as the willing and resourceful actors on the world stage of the struggle for supremacy between Catholicism and Protestantism. The Vita mirabilis et mors pretiosa was, in this sense, a very political book, an intrinsic part of the Papal See's attempt to return England to the Catholic Faith.

Quite apart from its ideology, though, the fact that Vita mirabilis et mors pretiosa was written by an Englishman had an important bearing on the distinctiveness of its execution. It was written in a style that was destined to be highly popular with Catholic audiences all around the world, as the numerous translations mentioned above attest. In the period under discussion, indeed, hagiography was one of the dominant literary genres, ${ }^{87}$ but over time, as Hermione Lee has suggested, its focus had changed; the Saints' Lives became more 'psychologically complex', and 'more interested in the saints' conversions and self-doubts than in lists of miracles' ${ }^{88}$ The emergence of individualism in the Early Modern period had an impact on the ways individuals thought about themselves and narrated their lives. As Lee suggests: 'The range of subjects thought appropriate for a Life broadened with the rise of the middle classes and with social movements towards democracy. By the later $17^{\text {th }}$ and $18^{\text {th }}$ centuries, more "private" Lives were being written and much more emphasis was being placed on

\footnotetext{
${ }^{85}$ At Bornhem in 1663, Torre refused to consent to changes in the curriculum - some of the Dominicans offered to teach theology as well as philosophy - but, as Raymond Palmer suggests, ' $F$. Vincent Torre, however, dissented and began his school of philosophy, which even those who had gone though that branch of studies were required to attend. Much discontent was aroused, and the matter ended by the majority of the Religious being dispersed'; see 'In Exile, Part l', in Palmer's collection of essays, Dominicana (n.d.; contained in the Douai Abbey Archives) pp. 581-602 (p. 592). In November 1665, F. Thomas Fidden was appointed to a vacant post in Bornhem, and 'F. Vincent Torre gladly surrendered his charge, for his severe rule had been disliked and in 1666 he departed to London', 'In Exile, Part I', Dominicana, p. 593. The essay 'In Exile, Part I', is noted as having been extracted from a volume, Merry England.

${ }^{86}$ As Raymond Palmer has noted, Vincent Torre, died on 24 August 1687; see Raymond Palmer, O.P., Obituary Notices of the Friar-Preachers, or Dominicans, of the English Province, p. 4.

${ }^{87}$ For an overview see Thomas J. Heffernan, Sacred Biography.

${ }^{88}$ Hermione Lee, Biography: A Very Short Introduction (Oxford: Oxford University Press, 2009), p. 25.
} 
ideas of selfhood and the autonomy of the individual' (Lee, p. 29). Hansen [Torre] was part of a new generation of biographers who sought to bring into their own work some of the techniques of lifewriting - including the use of the 'vast treasure of conversations', 'life in scenes', and the adroitly chosen detail - as they were emerging and taking shape throughout the latter half of the seventeenth century, precisely those that would lead triumphantly to James Boswell's masterpiece of the following century, The Life of Samuel Johnson (1791). ${ }^{89}$

In setting out to create a new biography of Rose of Lima, Hansen [Torre] had an enormous treasuretrove of information about Rosa's everyday life at his disposal, for he had read and absorbed the Ordinary Process (1617-18) as well as the Apostolic Process (1630-32), but what he did was scour those materials in a non-traditional way. Rather than use the documents to adduce proof of the answers to the dogmatic questions that were devised by the Holy See to prove that Rosa was a saint, he leap-frogged the apologetic process and drew inspiration from the details of Rosa's life provided especially by her mother, María de Oliva, and her Indian maidservant Mariana de Oliva, in order to create an account that satisfied the need for proof about her saintliness (i.e. her virtues and her miracles) but also provided an individual portrait of her life based on particular details, conversations and scenes from her everyday life. It was a formula that proved to be highly successful in drawing the reader in.

Some of the conversations Rosa had with her close family - her mother, her brother and her maid are recounted in Hansen [Torre]'s account, and these provide a great deal of insight into Rosa's inner life. One of the best examples of this is the conversation that Rosa had with her brother, Hernando, when a young girl about her hair; he had scattered some dirt in her hair and when she complained, in Hansen [Torre]'s version, Hernando said the following: 'Inquit soror mea, si te deturpati capillitii tui iniuria tam serio affligit, scito, cultos puellarum cincinnos Inferni rudentes esse, quibus illa queantur iuvenum incautae animae, ut in gehennam aeaternam detrahantur. Ergo puta exosos Deo capillos, quos tu amare videris. ${ }^{90}$ Hansen [Torre] is careful to provide the transcription of Hernando's words, as well as the deep impact these had on Rosa, causing her to dedicate her life to God, in order to avoid sending young men to hell as a result of her beautiful locks. Other examples of vivid conversations are provided in the recounting of the exchanges between Rosa and her mother Hansen [Torre] is always careful to bring out the drama of the words. In Chapter III, for example, we are introduced to an exchange between Rosa and her mother bearing on the latter's attempt to heal Rosa of her ringworm. She put a vulture's pelt on her, and then was surprised, on finding that the vulture's pelt had created more harm than good, that her daughter had said nothing: 'Ut quid (:inquit) "tot dies noctesque exegisti sub his cruciatibus, nec abieiecisti pelles que sic te excarnificabant" replicuit morigera Filia: \& nonne diserte vetueras Mater, ne illas absque, tuo nutu deponerem obedini. ${ }^{\prime 91}$ Rosa is shown turning her mother's criticisms back to their source; it is powerfully done, and dramatic.

A good example of Hansen [Torre]'s skill in providing a sense of Rosa's life through scenes occurs in Chapter VIII when Rosa's habit of wearing a crown under her hood is discovered:

Casus erat: germanum Rosae fratrem ob puerile delictum Pater quaerebat ad virgidemiam: interiecit se blandiuscule Rosa patris iram propitiatura; is vero dum filiam sibi obstantem impetuose dimovet, fortuito manus errore impegit leviter in caput virginis ea parte qua tecta

\footnotetext{
89 See Harold Nicholson, The Development of English Biography (London: Hogarth Press, 1928); Bruce Redford (Oxford: Oxford University Press, 2002), and Lee, Biography: A Very Short Introduction, pp. 39-53.

90 'He said: "My dear sister, if your sullied hair afflicts you so much as to be a serious injury, you should know that the curled locks of hair of young women are the ropes of hell, as a result of which the unwary souls of young men are dragged down to eternal hell. Therefore reflect upon those locks of hair that so hate God, and which you seem to love"'; Hansen [Torre], Vita mirabilis et mors pretiosa, chapter II, p. 7.

91 'As a result of which, she said: "Why did you persevere so much - for days and for nights - and put up with these torments, so much so that you didn't even take off the pelts that were excoriating your own skin." And her compliant daughter replied: "But surely you recall, mother, how eloquently you forbade me from removing those very pelts, and not until you commanded it"; Hansen [Torre], Vita mirabilis et mors pretiosa, Chapter III, p. 13. For the mother's less dramatic account of this event, see Hart (ed.), Edición crítica del Proceso Apostólico, fols. 145v-46r, p. 177.
} 
corona caviebat: mox improvisum ictum tres sanguinis rivi secuti frontem inocentis filiae decursim purpurarunt, manifesto satis indicio qualis herinaceus sub candido eius regime clam nidularetur (...)..$^{92}$

The way in which Hansen [Torre] sets up the scene - describing the argument between Gaspar Flores and his son, Hernando, which occurred while Rosa was watching, followed by Rosa's sudden interposition of her body between her father and brother - sets up the drama powerfully, ready for the blow that Rosa takes on her own head when trying to protect her brother. The detail of the 'three rivulets of blood' ('tres sanguinis rivi') particularises the scene, adding a metaphorical layer (Rosa's gesture is compared to that of Christ via the image of His blood shed for others) to its inherent drama. The description of the aftermath of the event recounted by Hansen [Torre] - Rosa rushes to her room, attempting to hide the blood, with her mother in hot pursuit - adds further dramatic depth to the scene. Though clearly used for its doctrinal and instructional qualities (it illustrates that Rosa was not afraid to suffer corporeal pain in order to protect others, and therefore possessed Christ-like qualities), this scene demonstrates that Hansen [Torre] was also keen to extract and express the inherent dramatic qualities of the scene in order to create a more vivid impact on the reader's imagination.

The English biographer, as the use of the detail of the 'three rivulets of blood' in the above scene suggests, was adept at employing vivid details in order to express the specific charateristics of a person or event in order to bring it alive. When recounting the episode of Rosa's life when she decided to run away from home and join a convent, but was prevented from doing so by being rendered immobile when she went into Santo Domingo Church to pray before the Virgen del Rosario, Hansen [Torre] uses various metaphors, including the image of a 'most hidden net', to conjure up the sense of an externally imposed immobilisation: 'At Rosa, quod loco movere se neutiquam posset erubescens una que dissimulans tentabat subinde, si quo se tanti prodigii secretissimo retinaculo explicaret. ${ }^{\prime 93}$ And when Rosa promises that she will desist from her project and return to look after her mother and grandmother, the power holding her is released: 'Mirum dictum! repente quae plumbum fuerat, se plumam sensit. ${ }^{94}$ By describing the change in terms of a transformation from lead to a feather, Hansen [Torre] is able to clothe this miraculous event in verisimilitude. And he was able to enhance the justice of his metaphor by choosing two comparative terms that are phonetically similar ('plumbum' and 'plumam'. Here we see an adept narrator who provides a sense of the drama of Rosa's life through his attention to vivid descriptive details as well as the use of striking metaphors and similes. There are, of course, no 'ropes of hell', nor 'hedgehogs', nor 'most secret nets' in the depositions about Rosa's life provided in the Ordinary Process nor, indeed, in the Apostolic Process. ${ }^{95}$ Hansen [Torre] builds a picture of Rosa's life following in the traditional Catholic mould of the canonic Saint's Life, but also drew on some of the some techniques of the English biographical method

\footnotetext{
92 'It happened as follows: their father was seeking to punish Rosa's blood brother for a puerile crime he had committed: and Rosa, seeking to appease her father's anger, threw herself in between in a gesture designed to soften her father's resolve; and he, in truth while seeking to remove her since she was obstructing him, did so impetuously, and by chance and in error, his hand landed lightly on the virgin's head on that part where the crown lay concealed; soon after the unexpected blow had fallen three rivulets of blood, one after the other, ran down and turned the innocent young girl's forehead red, a clear sign that something akin to a hedgehog was secretly nesting under her white vestment'; Hansen [Torre], Vita mirabilis et mors pretiosa, Chapter VIII, p. 54. 93 'And Rosa who could by no means remove herself from that place, blushing and attempting to conceal what was occurring, immediately afterwards wondered if such an unnatural event might be explained by a most hidden net'; Hansen [Torre], Vita mirabilis et mors pretiosa, Chapter IV, p. 22.

94 'And - marvelous to tell - suddenly what had been like lead felt as light as a feather'; Hansen [Torre], Vita mirabilis et mors pretiosa, Chapter IV, p. 23.

${ }^{95}$ For an account in the original documents of the disagreement about Rosa's hair, see chapter 2 of the chronology in the Apostolic Process, 'Vida, muerte y milagros de Soror Rosa de Santa María...', Hart (ed.), Edición crítica del Proceso Apostólico, fol. 686v, p. 523; for an account of the blood dripping down Rosa's forehead, see her mother's account in Hart (ed.), Edición crítica del Proceso Apostólico, fols. 165v-66v, p. 192; for a description of Rosa's immobilization see chapter 7 of 'Vida, muerte y milagros de Soror Rosa de Santa María...', Hart (ed.), Edición crítica del Proceso Apostólico, fols. 699r-v, p. 532.
} 
characteristic of the second half of the seventeenth century in order to make the story more vivid and more real.

In this study of the biographical fashioning of Santa Rosa I have drawn attention to a number of disjunctions between the various narratives created about Rosa's life: those that exist, firstly, between the miracles as understood by the 'man in the street' in Lima and the miracles as they are understood and determined by the Holy See; and those, secondly, existing between the deliberations of the Sacred Congregation of Rites and the first official Latin biography, the Vita mirabilis et mors pretiosa. The fact that the latter text was written not by a German Dominican called Leonardus Hansen (who, in fact, did not exist), but by an elusive English Dominican by the name of Vincent Torre has important implications for the way in which we interpret Santa Rosa's highly influential first official biography. The first conclusion that can be drawn is that the Vita mirabilis et mors pretiosa was part and parcel of the Popish Plot and constituted a coded attempt to being England back to the 'true faith'. Secondly, it is now clear that its true author, Vincent Torre, drew on a number of the techniques used in the biographical tradition that was bearing fruit at that time in England, including the recording and exploitation of everyday speech, the use of drama, and the employment of striking visual metaphors. The Vita mirabilis et mors pretiosa was famous for other reasons than simply the telling of the life of the first saint of the Americas, and this is no doubt why it was such a colossal seventeenth-century international best-seller. 